\title{
PENGARUH KEPEMIMPINAN, LINGKUNGAN KERJA, DAN FASILITAS KANTOR TERHADAP KINERJA PERANGKAT DESA DI KECAMATAN KAMPAR
}

\author{
Dedi Wahyudi ${ }^{1}$, Abshor Marantika ${ }^{2}$, Yusup $^{3}$ \\ STIE Bangkinang \\ abshormarantika@pascabangkinang.ac.id
}

\begin{abstract}
Organizations in achieving goals with all the processes require a leadership role. Through capable leaders, they can directly monitor and direct and provide positive input for their employees. This will raise the interest of employees to work harder and produce maximum work results. The work environment needs to be considered to improve performance, because agencies that have a good and comfortable work environment will motivate their employees to work more enthusiastically and passionately. In addition, work facilities are also very necessary in improving the performance of village officials, with complete work facilities, it is hoped that it will be very helpful in completing office tasks so that the resulting performance will be maximal. The purpose of this study was to determine whether there was an influence of leadership, work environment, and office facilities on the performance of village officials in Kampar District. The population in this study were all village officials in the Kampar sub-district, as many as 189 village officials. While the samples taken were 128 village officials obtained from the Slovin formula with an error rate of 5\%. The data collection method used in this research is using a questionnaire. Data analysis used descriptive percentage analysis method, multiple linear regression analysis, classical assumption test analysis, and hypothesis testing analysis with the help of SPSS program. The results of this study are that there is a positive and significant influence of leadership, work environment and office facilities on the performance of village officials in Kampar District. Suggestions in this study are suggested to village officials to optimize the use of windows as air ventilation and village office buildings in Kampar District need to be equipped with soundproofing. In addition, it is recommended that the village head completes and repairs social facilities that are felt to be lacking or have been damaged.
\end{abstract}

Keywords Performance, Leadership, Work Facilities, Work Environment

\section{PENDAHULUAN}

Kinerja pegawai yang baik secara langsung akan mempengaruhi kinerja organisasi atau instansi dan untuk memperbaiki kinerja pegawai tentu merupakan suatu pekerjaan yang memakan waktu dan proses yang panjang. Selain dengan meningkatkan pengawasan dan pembinaan, juga dilakukan penilaian terhadap tingkat keberhasilan kinerja yang telah dilakukan oleh para pegawainya melalui peran pemimpin yang cakap memimpin instansi tersebut. Menurut Handoko (2017), kepemimpinan merupakan bagian penting dari organisasi karena dalam kegiatannya pimpinan dapat mempengaruhi moral 
dan kepuasan kerja, keamanan, kualitas kehidupan kerja dan terutama tingkat prestasi suatu organisasi.

Hasil penelitian I Wayan Arta Artana (2012) membuktikan bahwa kepemimpinan memiliki pengaruh yang positif dan signifikan terhadap kinerja pegawai. hal ini berarti kepemimpinan yang baik dan orang yang tepat sebagai seorang pemimpin dapat meningkatkan kinerja pegawai. Pemimpin yang cakap tentunya dapat melakukan pantauan langsung serta mengarahkan dan memberikan masukan positif bagi pegawainya. Hal ini akan memunculkan minat pegawai untuk bekerja lebih giat dan menghasilkan hasil kerja yang maksimal. Selain kepemimpinan, kondisi lingkungan kerja yang nyaman akan mempengaruhi pegawai bekerja lebih giat dan konsentrasi menyelesaikan tugas-tugasnya sesuai jadwal. Keberhasilan peningkatan kinerja menuntut instansi mengetahui sasaran kinerja. Jika sasaran kinerja ditumbuhkan dari dalam diri pegawai akan membentuk suatu kekuatan diri dan jika situasi lingkungan kerja turut menunjang maka pencapaian kinerja akan lebih mudah. Instansi yang mempunyai lingkungan kerja yang baik dan nyaman akan memberikan motivasi bagi pegawainya untuk meningkatkan kinerjanya. Selain itu, kondisi kerja yang baik akan membantu mengurangi kejenuhan dan kelelahan. Sehingga diharapkan dapat meningkatkan kinerja.

Menurut Nitisemito (2014), lingkungan kerja adalah sesuatu yang ada disekitar para pekerja dan dapat mempengaruhi dirinya dalam menjalankan tugas yang dibebankannya. Instansi harus dapat memperhatikan kondisi yang ada dalam organisasi baik di dalam maupun di luar ruangan tempat kerja, sehingga pegawai dapat bekerja dengan lancar dan merasa aman. Hasil penelitian I Wayan Arta Artana (2012) membuktikan bahwa lingkungan kerja menempati urutan pertama atau berpengaruh dominan terhadap kinerja pegawai. Oleh sebab itu, disarankan kepada pimpinan untuk memperbaiki lingkungan kerja sesuai dengan tugas dan tanggung jawab. Selain kepemimpinan dan lingkungan kerja, fasilitas yang layak dan memadai akan mempengaruhi kelancaran aktivitas pekerjaan dan pegawai akan lebih bersemangat untuk mencapai sasaran-sasaran organisasi. Menurut Moenir (1987), fasilitas adalah segala sesuatu yang digunakan, dipakai, ditempati, oleh pegawai baik dalam hubungan lingkungan dengan pekerjaan maupun untuk kelancaran pekerjaan.

Dari pengertian di atas fasilitas dapat dibagi 3 golongan yaitu: (1) fasilitas alat kerja operasional, (2) fasilitas sosial, (3) fasilitas perlengkapan kerja. Observasi awal yang dilakukan di 17 Kantor Desa di Kecamatan Kampar populasi 189 perangkat desa. Dilihat dari aspek pendidikan perangkat desa yang berpendidikan SD ada 21 orang, SMP ada 77 orang, SMA ada 85 orang, S1 ada 6 orang yang secara umum memenuhi kemampuan dan dilihat dari aspek kesiapan bekerja menunjukkan sama. Serta rata-rata perangkat desa mempunyai pengalaman kerja di atas 5 tahun. Selain itu, untuk aspek kompensasi perangkat desa disamping mendapatkan gaji setiap bulan dan tanah bengkok desa. Perangkat desa juga mendapatkan tunjangan per bulan dari kebijakan yang sesuai dengan kesepakatan dari desa, selain berupa tunjangan perangkat desa diberikan kebijakan untuk masuk 5 (lima) hari kerja yaitu senin sampai dengan hari jumat.

Kebijakan 5 (lima) hari kerja ini merupakan kebijakan dari pemerintah tingkat desa di Kecamatan Kampar dengan maksud agar hari sabtu dan minggu perangkat desa dapat beristirahat atau melakukan kegiatan lainnya di luar pekerjaan di kantor desa. Berdasarkan hasil angket kinerja yang dibagikan secara acak kepada 65 perangkat desa dari 17 Kantor Desa di Kecamatan Kampar, dapat dilihat bahwa untuk kualitas kinerja perangkat desa menunjukkan $26,15 \%$ perangkat desa masih dalam kriteria kurang baik dan 3,07\% dalam kriteria sangat kurang baik. Untuk kuantitas kinerja perangkat desa 
menunjukkan 50,76\% dalam kriteria kurang baik. Dengan demikian menunjukkan masih ada perangkat desa yang menyelesaikan pekerjaan kurang teliti dan rapi. Serta masih ada perangkat desa yang kurang memahami tugas yang diberikan.

Pekerjaan yang ada terkadang penyelesaiannya tidak tepat pada waktunya hal ini dikarenakan masih ada perangkat desa yang menunda-nunda waktu dalam menyelesaikan pekerjaan. Dilihat dari tingkat kehadiran perangkat desa juga masih terdapat perangkat desa yang berangkat dan pulang kantor tidak sesuai dengan jam yang telah ditentukan. Bahkan masih terdapat perangkat desa pada saat jam kerja masih ada yang keluar kantor tanpa ijin. Hal ini juga sesuai dengan hasil observasi yang dilakukan pada masyarakat Kecamatan Kampar yang merupakan pengguna jasa kantor desa menilai bahwa pelayanan yang diberikan kurang memberikan kepuasan.

Salah satu penduduk di kantor Desa Tanjung Rambutan misalnya yang namanya tidak boleh disebut mengungkapkan bahwa jam kerja kantor desa yang seharusnya dimulai pada pukul 07.30 WIB malah dimulai pukul 08.45 WIB. Selain itu pelayanan yang diberikan juga membutuhkan waktu yang lama. Serta jam kerja yang berlaku di kantor desa seperti kantor desa lainnya hanya sampai pukul $12.00 \mathrm{WIB}$, lebih dari jam tersebut kantor desa sudah tutup. Dan seharusnya jam kerja berakhir pada pukul 13.30 WIB. Sehingga keadaan yang demikian mengakibatkan kurang optimalnya penyelesaian tugas dan tanggung jawab yang harus mereka selesaikan. Instansi kantor desa di Kecamatan Kampar adalah instansi pemerintah yang berdiri di bawah pemerintah daerah Kabupaten Kampar. Instansi kantor desa merupakan organisasi pemerintah terendah yang memiliki tanggung jawab melayani dan memberikan kontribusi kepada masyarakat secara langsung. Sehingga perangkat desa (pegawai) harus mempunyai kemampuan dalam pelayanan dan memberikan kontribusi yang baik dan maksimal kepada masyarakat.

Berdasarkan latar belakang tersebut, penulis ingin melakukan penelitian mengenai Pengaruh Kepemimpinan, Lingkungan Kerja, dan Fasilitas Kantor terhadap Kinerja Perangkat Desa di Kecamatan Kampar. Sehingga permasalahan yang muncul adalah apakah ada pengaruh antara kepemimpinan dengan kinerja perangkat desa, apakah ada pengaruh antara lingkungan kerja dengan kinerja perangkat desa, apakah ada pengaruh antara fasilitas kantor dengan kinerja perangkat desa dan apakah kepemimpinan, lingkungan kerja, dan fasilitas kantor bersama-sama mempengaruhi kinerja perangkat desa di Kecamatan Kampar. Adapun tujuan dari penelitian yang berjudul adalah untuk mengetahui pengaruh antara kepemimpinan dengan kinerja perangkat desa, untuk mengetahui pengaruh antara lingkungan kerja dengan kinerja perangkat desa, untuk mengetahui pengaruh antara fasilitas kantor dengan kinerja perangkat desa dan untuk mengetahui pengaruh secara bersama-sama antara kepemimpinan, lingkungan kerja, dan fasilitas kantor dengan kinerja perangkat desa di Kecamatan Kampar.

\section{LANDASAN TEORI Kinerja}

Menurut Mathis dan Jackson (2002), Kinerja (performance) pada dasarnya adalah apa yang dilakukan atau tidak dilakukan oleh karyawan. Menurut Prawirosentono (Lijan Poltak Sinambela, 2012), kinerja adalah hasil kerja yang dapat dicapai oleh seseorang atau sekelompok orang dalam suatu organisasi, sesuai dengan wewenang dan tanggung jawabnya masing-masing, dalam upaya mencapai tujuan organisasi bersangkutan secara legal, tidak melanggar hukum dan sesuai dengan moral dan etika. Sedangkan menurut 
Mangkunegara (2009), kinerja merupakan hasil kerja secara kualitas dan kuntitas yang dicapai seorang pegawai dalam melaksanakan tugasnya sesuai dengan tanggung jawab yang diberikan kepadanya.

Berdasarkan pengertian dari beberapa pendapat ahli mengenai kinerja dan karyawan di atas, dapat disimpulkan bahwa kinerja karyawan adalah seseorang yang memberikan kontribusi dari segi kuantitas dan kualitas output dari pekerjaan yang mereka lakukan sesuai dengan wewenang dan tanggung jawab yang diberikan organisasi dalam upaya mencapai visi, misi, dan tujuan organisasi bersangkutan secara legal, tidak melanggar hukum dan sesuai dengan moral maupun etika.

Mangkunegara (2009) menyatakan bahwa faktor yang mempengaruhi kinerja antara lain faktor kemampuan (ability), faktor motivasi. Sedangkan menurut Wirawan (2009) kinerja pegawai merupakan hasil sinergi dari sejumlah faktor, faktor internal pegawai, faktor lingkungan internal organisasi dan faktor lingkungan eksternal organisasi. Penilaian kinerja karyawan sangat bermanfaat bagi pertumbuhan dinamika sebuah organisasi secara keseluruhan, melalui penilaian dapat diketahui bagaimana kondisi riil pegawai dilihat dari kinerja dan data itu dapat digunakan sebagai pertimbangan dalam pengambilan keputusan. Beberapa pendekatan untuk mengukur sejauh mana karyawan mencapai suatu kinerja secara individual menurut Mathis dan Jackson (2002) adalah kuantitas output, kualitas output, jangka waktu output, kehadiran di tempat kerja dan kemampuan bekerja sama

\section{Kepemimpinan}

Menurut Rivai (2006), kepemimpinan adalah proses mempengaruhi atau memberi contoh dari pemimpin kepada pengikutnya dalam upaya mencapai tujuan organisasi. Handoko (1997) mengatakan bahwa kepemimpinan adalah kemampuan yang dipunyai seseorang untuk mempengaruhi orang lain agar bekerja untuk mencapai tujuan dan sasaran. Sedangkan menurut Hamalik (2007), "Kepemimpinan adalah suatu proses pemberian petunjuk dan pengaruh kepada anggota kelompok atau organisasi dalam melaksanakan tugas-tugas. Berdasarkan pengertian kepemimpinan dari beberapa pendapat ahli di atas, dapat disimpulkan bahwa kepemimpinan atau leadership merupakan suatu proses mempengaruhi perilaku orang lain agar berperilaku seperti yang akan dikehendaki. Selain itu, kepemimpinan adalah sebagai kemampuan untuk mempengaruhi suatu kelompok kearah tercapainya tujuan.

Fungsi kepemimpinan berhubungan dengan situasi sosial dalam kehidupan kelompok atau organisasi dimana fungsi kepemimpinan harus diwujudkan dalam interaksi antar individu. Menurut Rivai (2006) secara operasional fungsi pokok kepemimpinan dapat dibedakan atas fungsi instruksi, fungsi konsultasi, fungsi partisipasi, fungsi delegasi, dan fungsi pengendalian. Dalam melaksanakan fungsi-fungsi kepemimpinan, maka akan terlihat gaya kepemimpinan. Gaya kepemimpinan tersebut akan mengklasifikasikan tipe kepemimpinan. Gaya kepemimpinan memiliki tiga pola dasar, yaitu gaya kepemimpinan yang berpola pada kepentingan pelaksanaan tugas, pola pada pelaksanaan hubungan kerja sama dan pola pada kepentingan hasil yang dicapai. Berdasarkan ketiga pola dasar tersebut terbentuk perilaku kepemimpinan yang berwujud pada kategori kepemimpinan yang terdiri dari tipe kepemimpinan otoriter, tipe kepemimpinan kendali bebas, tipe kepemimpinan demokratis. Sedangkan menurut Sunindhia dan Ninik (1993) tipe kepemimpinan dapat digolongkan menjadi 6 yaitu tipe otokratis, tipe militeristis, tipe paternalistis, tipe kharismatis, tipe laisses faire, dan tipe demokrasi. 
Menurut S.P. Siagian dalam Sunindhia dan Ninik, 1993) menyatakan bahwa terdapat tiga teori kepemimpinan yang menonjol, yaitu teori genetis (keturunan), inti dari teori ini menyatakan bahwa "leader are born and not made" (pemimpin itu dilahirkan sebagai bakat dan bukanya dibuat). Teori sosial, teori inipun merupakan ekstrim pada sisi lainnya. Inti aliran teori sosial ini ialah bahwa "leader are made and not born" (pemimpin itu dibuat atau dididik dan bukanya kodrati). Dan teori ekologis. Teori ini disebut teori ekologis pada intinya berarti bahwa seseorang hanya akan berhasil menjadi pemimpin yang baik apabila ia telah memiliki bakat kepemimpinan. Teori ini menggabungkan segisegi positif dari kedua teori terdahulu sehingga dapat dikatakan merupakan teori yang paling mendekati kebenaran. Edwin Ghiselli dalam buku Handoko (1997) mengemukakan tentang teori kesifatan atau sifat kepemimpinan yang merupakan indikator dari kepemimpinan itu sendiri. Sifat kepemimpinan tersebut yaitu kemampuan, kecerdasan, ketegasan dan kepercayaan diri.

\section{Lingkungan Kerja}

Lingkungan kerja adalah segala sesuatu yang ada di sekitar pegawai yang dapat mempengaruhi dirinya dalam menjalankan tugas-tugas yang dibebankan”. Dengan lingkungan yang bersih akan menimbulkan rasa senang dan rasa senang ini dapat mempengaruhi seseorang untuk bekerja lebih bersemangat dan lebih bergairah. Menurut Supardi (Ekaningsih 2012), lingkungan kerja merupakan keadaan sekitar tempat kerja baik secara fisik maupun non fisik yang dapat memberikan kesan menyenangkan, menentramkan, dan kesan betah bekerja. Sedangkan menurut Buchori Zainun (Jemmi Bernardi K dan Ernawati, 2010), Kinerja pegawai ditentukan oleh faktor-faktor lingkungan luar dan iklim organisasi. Berdasarkan pengertian dari beberapa pendapat ahli di atas, dapat disimpulkan bahwa lingkungan kerja adalah keadaan sekitar tempat kerja baik secara fisik maupun non fisik yang dapat mempengaruhi dimana karyawan melakukan aktivitas pekerjaan.

Ketidaknyamanan saat bekerja merupakan kondisi yang sangat tidak baik bagi tenaga kerja dalam beraktivitas, karena pekerja akan melakukan aktivitasnya yang kurang optimal dan akan menyebabkan lingkungan kerja yang tidak bersemangat dan membosankan, sebaliknya apabila kenyamanan kerja tercipta saat pekerja melakukan aktivitasnya maka pekerja akan melakukan aktivitasnya dengan optimal, dikarenakan kondisi lingkungan pekrjaan yang sangat baik dan mendukung serta akan memberikan kepuasan kerja tersendiri bagi pegawai. Menurut Sedarmayanti (2001) secara garis besar, jenis lingkungan kerja terbagi menjadi 2 yaitu lingkungan kerja fisik dan lingkungan kerja non fisik. Menurut Ahwari (Ekaningsih, 2012:22) faktor-faktor yang mempengaruhi lingkungan kerja, yaitu pelayanan pegawai, kondisi kerja dan hubungan pegawai. Menurut Sedarmayanti indikator lingkungan kerja, yaitu: penerangan cahaya, suhu udara, suara bising, keamanan kerja dan hubungan pegawai.

\section{Fasilitas}

Fasilitas berasal dari bahasa Belanda faciliteit adalah sarana prasarana atau wahana untuk mempermudah melakukan sesuatu (Moenir, 1978). Fasilitas bisa pula dianggap sebagai suatu alat, fasilitas biasanya dihubungkan dalam pemenuhan suatu prasarana umum yang terdapat dalam suatu perusahaan-perusahaan ataupun organisasi tertentu. Contohnya: fasilitas kantor, seperti mobil, motor, dan lain-lain. Sedangkan menurut Moenir (1987), fasilitas kantor adalah segala sesuatu yang digunakan, dipakai, ditempati, dan dinikmati oleh pegawai baik dalam hubungan langsung dengan pekerjaan 
maupun untuk kelancaran pekerjaan”. Dari batasan pengertian mengenai fasilitas kantor tersebut, dapat disimpulkan secara sederhana bahwa fasilitas kantor adalah peralatan atau perlengkapan yang digunakan secara langsung maupun tidak langsung untuk memperlancar suatu pekerjaan.

Menurut Moenir (1987) mengungkapkan bahwa indikator fasilitas yaitu fasilitas alat kerja operasional, fasilitas perlengkapan kerja (Gedung dengan segala sarana yang diperlukan, termasuk jalan, selokan, air bersih, pembuangan air kotor dan halaman parkir, ruangan kerja, penerangan yang cukup dan lain-lain), fasilitas sosial.

\section{Hipotesis}

Hipotesis penelitian ini adalah:

1. Ada pengaruh positif dan signifikan antara kepemimpinan dengan kinerja perangkat desa di Kecamatan Kampar

2. Ada pengaruh positif dan signifikan antara lingkungan kerja dengan kinerja perangkat desa di Kecamatan Kecamatan Kampar.

3. Ada pengaruh positif dan signifikan antara fasilitas kantor dengan kinerja perangkat desa di Kecamatan Kampar.

4. Ada pengaruh positif dan signifikan secara bersama-sama antara kepemimpinan, lingkungan kerja, dan fasilitas kantor dengan kinerja perangkat desa di Kecamatan Kampar

\section{METODOLOGI PENELITIAN}

Penelitian ini adalah penelitian kuantitatif. Desain penelitian yang digunakan dalam penelitian ini adalah desain korelasional untuk mencari pengaruh antara variabel bebas (X) dan varibel terikat (Y). Penelitian ini dilakukan pada 17 Kantor Desa di Kecamatan Kampar Kantor Desa di Kecamatan Kampar Kabupaten Kampar. Penelitian akan dilakukan selama 3 bulan yang dimulai pada Bulan Mei 2021 sampai Bulan Juli 2021. Populasi dalam penelitian ini adalah seluruh perangkat desa di 17 kantor desa di Kecamatan Kampar yang berjumlah 189 orang. Penelitian ini menggunakan teknik sampel probability sampling. Sampel diambil dari total populasi yang berjumlah 189 orang dan diambil sampel sebanyak 128 orang yang terdiri dari sekretaris desa, kaur umum, kaur keuangan, kasi pemerintahan, kasi pembangunan, kasi pertanian dan pengairan, kasi trantib dan linmas, kasi kesra dan kadus.

Pada penelitian ini digunakan data primer dan data sekunder. Metode pengampilan sampel dilakukan dengan angket atau kuisioner, metode dokumentasi dan metode observasi. Tapahan analisis data dilakukan dengan uji instrument yang terdiri dari uji validitas dan rentabilitas dan dilanjutkan dengan uji hipotesis. Pengujian hipotesis dalam penelitian ini dilakukan dengan menggunakan uji simultan (Uji-F) dan uji parsial (uji-t), yang diperoleh melalui analisis regresi linear berganda, dengan persamaan sebagai berikut :

$\mathrm{Y}=\alpha+\beta_{1} \mathrm{X}_{1}+\beta_{2} \mathrm{X}_{2}+\beta_{2} \mathrm{X}_{2}+\epsilon$

Keterangan: $\mathrm{Y}=$ Kinerja Pegawai, $\mathrm{X}_{1}=$ Kepemimpinan, $\mathrm{X}_{2}=$ Lingkungan kerja $\mathrm{X}_{3}=$ Fasilitas Kerja, $\alpha=$ Konstanta, $\beta_{1}, \beta_{3}=$ Koefisien Regresi

$\epsilon \quad=$ Error Term atau Faktor Penganggu

Pengujian asumsi klasik bertujuan apakah model regresi linear berganda yang digunakan sebagai alat analisis sudah layak atau tidak. Berikut jenis-jenis pengujian asumsi klasik, yaitu uji normalitas, uji multikolineritas, dan uji heterokedastisitas. 
Selanjutnya dalam pengolahan data hasil penelitian ini, digunakan paket program Statistical Product and Service Solution (SPSS) versi 25.00.

\section{HASIL PENELITIAN}

\section{Hasil Pengujian Validitas dan Reliabilitas}

Berdasarkan hasil pengolahan data yang menunjukkan bahwa $r_{h i t u n g}>r_{\text {tabel. }}$. Dapat dikatakan bahwa pernyataan di dalam variabel kepemimpinan semuanya valid sehingga semua pernyataan dalam angket kepemimpinan sebanyak 14 pernyataan dapat digunakan dalam pengambilan data sehingga tidak ada pernyataan yang dibuang. Hasil pengujian validitas untuk variabel lingkungan kerja menunjukkan bahwa rhitung> rtabel, dikatakan bahwa pernyataan di dalam variabel lingkungan kerja ada yang tidak valid, yaitu pernyataan nomor 23, sehingga pernyataan nomor 23 tidak dapat digunakan dalam pengambilan data dan pernyataan tersebut harus dibuang karena pada masing-masing indikator yang sama sudah ada pernyataan yang mewakili, serta 10 pernyataan yang telah valid dapat digunakan dalam pengambilan data.

Hasil pengolahan data untuk uji validitas variabel lingkungan kejra menunjukkan bahwa $r_{\text {hitung }}>\mathrm{r}_{\text {tabel. }}$. Demikian dapat dikatakan bahwa pernyataan di dalam variabel fasilitas kantor ini semuanya valid sehingga semua pernyataan dalam angket fasilitas kantor sebanyak 21 pernyataan dapat digunakan dalam pengambilan data sehingga tidak ada pernyataan yang dibuang. Hasil pengolahan data untuk uji validitas dari instrument variabel kinerja menunjukkan bahwa $r_{\text {hitung }}>r_{\text {tabel. }}$. Demikian dapat dikatakan bahwa pernyataan di dalam variabel kinerja semuanya valid sehingga semua pernyataan dalam angket kinerja sebanyak 13 pernyataan dapat digunakan dalam pengambilan data, sehingga tidak ada pernyataan yang harus dibuang. Selanjutnya dapat dilihat hasil uji Reliabilitas.

Tabel 1: Hasil Uji Reliabilitas

\begin{tabular}{|c|l|c|c|c|}
\hline No & Variabel & $\begin{array}{c}\text { Cronbach`s } \\
\text { Alpha }\end{array}$ & $\begin{array}{c}\text { Standar Minimum } \\
\text { Cronbach`s Alpha di } \\
\text { Syaratkan }\end{array}$ & Keterangan \\
\hline 1 & Kepemimpinan & 0.848 & 0.70 & Reliabel \\
\hline 2 & Lingkungan Kerja & 0.794 & 0.70 & Reliabel \\
\hline 3 & Fasilitas Kantor & 0.912 & 0.70 & Reliabel \\
\hline 4 & Kinerja & 0.912 & 0.70 & Reliabel \\
\hline
\end{tabular}

\section{Sumber : Hasil Pengolahan Data}

Dari pengujian yang telah dilakukan dapat diketahui bahwa hasil Cronbach's Alpha setiap variabel lebih dari Standart Minimum Cronbach's Alpha yang disyaratkan, yaitu 0,70. Suatu konstruk atau variabel dikatakan reliabel jika memberikan nilai Cronbach's Alpha $>0,70$ Nunnally, dalam Imam Ghozali (2011). Output SPSS untuk uji reliabilitas akan dihasilkan secara bersama-sama dengan hasil validitas. Maka variabel kepemimpinan, lingkungan kerja, fasilitas kantor dan kinerja adalah reliabel.

\section{Hasil Uji Asumsi Klasik}

Dari hasil pengujian diperoleh nilai VIF untuk variabel kepemimpinan, lingkungan kerja, dan fasilitas kantor jauh di bawah 10. Sedangkan hasil uji melalui nilai toleransi untuk variabel kepemimpinan, lingkungan kerja, dan fasilitas kantor diatas 0,1 . Dengan demikian dapat disimpulkan bahwa dalam penelitian ini tidak ada 
multikolinieritas dalam regresi. Hasil uji heteroskedastisitas dengan menggunakan grafik Scatterplot menunjukkan pola titik-titik yang menyebar di sekitar nol. Hal ini berarti tidak terjadi heteroskedastisitas. Selain itu, menggunakan uji glejser menunjukkan nilai signifikansi variabel independen (kepemimpinan, lingkungan kerja, dan fasilitas kantor) $>0.05$. Disimpulkan bahwa model regresi tidak mengandung heteroskedastisitas.

Uji normalitas menggunakan sample Kolmogorov-Smirnov dan grafik P-P Plot. Dasar pengambilan adalah nilai signifikansinya, jika nilai signifikansi $>0.05$ maka dapat disimpulkan bahwa data berdistribusi normal (Ghozali, 2011: 160). Berdasarkan perhitungan diperoleh nilai Kolmogorov-Smirnov 0,119>0.05 sehingga data dinyatakan berdistribusi normal. Sedangkan menggunakan grafik P-P Plot diketahui titik-titik yang dihasilkan mendekati garis diagonal. Sehingga dapat disimpulkan data tersebut berdistribusi normal.

\section{Hasil Pengujian Hipotesis}

Hasil perhitungan SPSS dengan melihat tabel coefficientsnya diperoleh model persamaan regresi yang dihasilkan yaitu : $\mathrm{Y}=3,669+0,274 \mathrm{X}_{1}+0,271 \mathrm{X}_{2}+0,268 \mathrm{X}_{3}$.

Persamaan tersebut menunjukkan bahwa arah garis yang berbentuk linier dan merupakan hubungan garis yang positif. Secara lebih rinci model persamaan tersebut mengandung makna bahwa konstanta sebesar 3,669 berarti jika variabel lain adalah nol, maka kinerja perangkat desa di Kecamatan Kampar Kabupaten Kampar sebesar 3,669. Koefisien kepemimpinan $\left(\mathrm{X}_{1}\right)$ sebesar 0,274 berarti jika variabel kepemimpinan mengalami peningkatan sebesar 1point sedangkan variabel lain konstan, maka akan menyebabkan kenaikan kinerja perangkat desa di Kecamatan Kampar sebesar 0,274. Koefisien lingkungan kerja $\left(\mathrm{X}_{2}\right)$ sebesar 0,271 berarti jika variable lingkungan kerja mengalami peningkatan sebesar 1point sedangkan variabel lain konstan, maka akan menyebabkan kenaikan kinerja perangkat desa sebesar 0,271. Koefisien fasilitas kantor $\left(\mathrm{X}_{3}\right)$ sebesar 0,268 berarti jika variabel fasilitas kantor mengalami peningkatan sebesar 1point sedangkan variabel lain konstan, maka akan menyebabkan kenaikan kinerja perangkat desa di Kecamatan Kampar sebesar 0,268.

Uji $\mathrm{F}$ dimaksudkan untuk mengetahui adanya pengaruh kepemimpinan, lingkungan kerja, dan fasilitas kantor terhadap kinerja perangkat desa di Kecamatan Kampar. Nilai hitung F sebesar 48,377 dengan signifikansi 0,000 $<0,05$, sehingga hipotesis alternative diterima. Maka dapat disimpulkan bahwa dalam penelitian ini ada pengaruh secara bersama-sama antara kepemimpinan, lingkungan kerja, dan fasilitas kantor terhadap kinerja perangkat desa di Kecamatan Kampar. Besarnya pengaruh diketahui dari nilai koefisien determinasi simultan $\left(\mathrm{R}^{2}\right)$ yang terlihat dari Model Summary kolom adjusted $\mathrm{R}$ square sebesar $052,8 \%$. Hasil pengujian hipotesis berpengaruh kepemimpinan terhadap kinerja perangkat desa dengan menggunakan uji parsial diperoleh nilai signifikansi $0,000<0,05$ dapat dismpulkan Ha diterima dan menolak Ho. Hal ini menunjukkan bahwa ada pengaruh kepemimpinan terhadap kinerja perangkat desa di Kecamatan Kampar. Pengaruh lingkungan kerja terhadap kinerja perangkat desa dengan menggunakan uji parsial diperoleh nilai signifikansi $0,001<0,05$ dapat disimpulkan Ha diterima dan menolak Ho.

\section{Pembahasan}


Kinerja merupakan hasil perbandingan antara pekerjaan yang dicapai dengan standar pekerjaan yang ditetapkan sesuai dengan tugas dan tanggung jawab masingmasing. Kualitas yang dihasilkan oleh pegawai dalam melaksanakan tugas, dilihat dari tingkat pencapaian kerja yang dihasilkan pegawai tersebut. Kepemimpinan ini ditunjukkan dengan gaya kepemimpinan yang diterapkan dalam organisasi. Gaya kepemimpinan ini juga dapat mempengaruhi kinerja aparatur. Apabila bawahan tidak menyukai gaya kepemimpinan yang digunakan oleh pemimpin, maka tidak menutup kemungkinan akan terjadi penurunan kinerja dari para apratur yang selanjutnya akan memperngaruhi kinerja organisasi. Selanjutnya kompetensi merupakan kemampuan yang dibutuhkan untuk melakukan suatu pekerjaan.

Peningkatan kompetensi adalah strategi yang diarahkan untuk meningkatkan kinerja aparatur dalam melaksankan pekerjaannya secara efisien, efektif dan bertanggung jawab. Aparatur akan meningkatkan kinerjanya apabila dia memiliki kompetensi yang tinggi, memiliki minat kerja yang tinggi dan yakin bahwa tujuannya akan tercapai. (Moeheriono 2012). Dengan adanya peningkatan kinerja dari aparatur berarti akan menjadikan individu tersebut bekerja lebih keras dan mampu meningkatkan kinerja organisasi.

Berdasarkan hasil uji statistik variabel kepemimpinan kepala desa yang terdiri atas tiga dimensi yaitu meliputi hubungan pimpinan dan anggota, struktur tugas, dan posisi kekuatan pemimpin. Dimensi hubungan pimpinan dan perangkat desa merupakan dimensi tertinggi, hal ini didukung oleh jawaban responden yang mayoritas melihat bahwa pemimpin dapat berkomunikasi dengan bawahan dengan baik dan memperlakukan bawahan dengan baik, tidak berperasangka buruk terhadap bawahan, kemudian kepala desa dapat memberikan motivasi untuk bawahannya, bersikap ramah terhadap bawahan dan juga warganya, banyak kesempatan bagi bawahan untuk menyampaikan saran, pertimbangan, atau pendapat, serta kepala desa dapat mengembangkan bawahannya. Sedangkan dimensi yang terendah adalah dimensi struktur tugas. Hal ini menunjukkan bahwa perencanaan yang dilakukan oleh kepala desa, pengarahan agar bawahannyas bekerja sesuai dengan tujuan, pengambilan keputusan yang tepat oleh kepala desa, pemberian tugas kepada bawahan masih dinilai kurang memuaskan oleh perangkat desa.

Hal tersebut merupakan konsekuensi dari pemerintah, karena Pemerintah Desa merupakan organisasi Pemerintah terdepan yang berhubungan langsung dengan masyarakat. Kegiatan apapun yang terjadi di wilayah Desa akan dipandang masyarakat sebagai tanggung jawab Pemerintah Desa. Kinerja pegawai Pemerintah Desa mudah diperhatikan dan dinilai oleh masyarakat. Masyarakat menilai bahwa kinerja pegawai Pemerintah Desa belum dapat merespon kebutuhan masyarakat secara optimal. Segenap jajaran pegawai Pemerintah Desa memerlukan perhatian ekstra dari berbagai pihak sebagai bahan pertimbangan para pembuat kebijakan, sehingga apa yang di harapkan oleh masyarakat dapat diwujudkan.

Pelayanan publik dengan segala aspeknya, pegawai Pemerintah Desa belum dapat merespon kebutuhan masyarakat secara optimal disebabkan berbagai faktor antara lain keterbatasan sumber daya manusia baik kuantitas maupun kualitas, sarana dan prasarana perkantoran yang belum memadai, keterbatasan dukungan anggaran dan wewenang dan lain sebagainya. Kinerja para pegawai pemerintah Desa-desa di Kecamatan Kampar, dalam melaksanakan tugas dan tanggung jawabnya sebagai abdi masyarakat, yang membantu dalam memberikan pelayanan kepada masyarakat belum dilaksanakan secara maksimal. 
Hal ini disebabkan karena ketidaksiapan dan juga kemampuan para pegawai kelurahan belum dimiliki secara obyektif. Hal ini terlihat pada kedisiplinan para pegawai Desa dalam menjalankan tugasnya juga belum diterapkan dengan baik oleh para pegawai. Kedisiplinan Kades yang lemah dalam mengawasi atau mengontrol pelaksanaan tugas yang dikerjakan oleh para pegawainya menyebabkan kinerja dari para pegawai Desa tidak dapat ditingkatkan. Hal tersebut dilihat dari kekosongan para pegawai pada jam-jam kerja atau para pegawai yang pulang lebih awal sebelum jam kerja berakhir. Sehingga masyarakat yang membutuhkan bantuan pelayanan publik tidak dapat mengurus keperluan yang mereka butuhkan, karena tidak adanya pegawai yang bertugas dalam bidangnya untuk membantu masyarakat tersebut. Kepemimpinan Kepala Desa di Kecamatan Kampar, perlu bersikap lebih proaktif dan tegas terhadap para pegawai, beliau dapat lebih mengenal dan memahami kondisi dari para pegawai untuk lebih meningkatkan kinerjanya untuk dapat mencapai tujuan organisasi yang diinginkan.

Peningkatan disiplin para pegawai pemerintah Desa di Kecamatan Kampar masih harus terus ditingkatkan agar dalam memberikan pelayanan kepada masyarakat dapat dilakukan secara maksimal dan dapat mengerjakan tugasnya dengan waktu yang relatif cepat, serta menghasilkan kualitas layanan yang memuaskan. Tugas kepemimpinan yang dijalankan oleh Kades di Kecamatan Kampar masih terus dapat ditingkatkan agar dalam memimpin organisasi Desa dapat dilaksanakan berdasarkan keahlian dan juga kemampuan yang telah dimilikinya. Faktor yang sangat mendukung kepemimpinan Kades dalam meningkatkan kinerja pegawai pemerintah kelurahan dapat dilihat dari cara Kades tersebut memperhatikan kebutuhan-kebutuhan yang diperlukan oleh para pegawainya, untuk dapat lebih meningkatkan kinerjanya agar dapat mencapai tujuan organisasi yang diinginkan.

Sebagaimana yang dijelaskan diatas, adapun yang menjadi faktor untuk meningkatkan kinerja pegawai adalah fasilitas kerja. Adanya fasilitas kerja memungkinkan untuk meningkatkan kinerja pegawai guna mencapai tujuan yang telah ditentukan oleh manajemen dengan segala potensi secara efektif dan efisien. Adapun yang menjadi masalah pada Kantor Desa di Kecamatan Kampar adalah minimnya fasilitas kerja sehingga menghambat kinerja pegawai. Fasilitas kantor juga sangat penting dalam menunjang kinerja pegawai. Pegawai tidak dapat melakukan pekerjaan yang ditugaskan kepadanya tanpa alat kerja dan perlengkapan kerja lainnya. Fasilitas kantor yang tidak dapat digunakan atau terbatas dapat menghambat pegawai dalam menyelesaikan pekerjaan, sebaliknya Fasilitas kantor yang cukup dan layak untuk dipakai akan dapat menunjang dalam penyelesaian pekerjaan dengan cepat dan tepat sehingga dapat menghasilkan kinerja yang maksimal.

Fasilitas kerja yang disediakan oleh kantor pemerintahan yang merupakan sarana dan prasarana untuk memudahkan pekerjaan. Fasilitas kerja yang memadai dengan kondisi yang layak pakai dan terpelihara dengan baik akan membantu kelancaran proses kerja dalam suatu organisasi. Pemberian fasilitas yang lengkap juga dijadikan salah satu pendorong untuk bekerja.. Murtiningsih (2012:89) dalam jurnalnya menyimpulkan bahwa, "Fasilitas kantor terbukti memiliki pengaruh yang signifikan secara parsial terhadap kinerja pegawai Satuan Polisi Pamong Praja Kabupaten Kediri. Berdasarkan hasil penelitian, menunjukkan bahwa fasilitas kantor tidak berpengaruh terhadap kinerja perangkat desa. Jadi fasilitas kerja pada kelurahan atau kantor kepala desa kecamataan kuwarasan kabupaten Kebumen saat ini tidak terlalu mempengaruhi kinerja aparatur desa, karena fasilitas yang ada sudah cukup baik dan tidak menganggu kinerja. Selain itu, dizaman sekarang jarang ditemui karyawan yang tidak memiliki komputer ataupun 
laptop. Hasil penelitian ini sesuai dengan penelitian sebelumnya yang dilakukan oleh (Lajatuma, Nuraiana, \& Murwani, 2017) yang menunjukkan bahwa disiplin kerja tidak berpengaruh terhadap kinerja aparatur desa.

Penelitian ini diperkuat dengan penelitian terdahulu oleh Agustina (2017) yang menyimpulkan bahwa fasilitas kantor memiliki pengaruh yang signifikan terhadap kinerja, Pendapat ini sejalan dengan Ganda Sirait (2018) bahwa fasilitas kantor memiliki pengaruh yang signifikan terhadap kinerja, yang berarti dapat disimpulkan semakin lengkapnya ketersediaan fasilitas kantor yang ada maka akan menjadikan semakin tingginya tingkat kinerja pegawai. Implikasi dari penelitian ini menjelaskan bahwa fasilitas kantor merupakan alat utama atau alat bantu dalam pelaksanaan pekerjaan yang bertujuan untuk mempermudah aktivitas kantor (Moenir 2015). Pada dasarnya fasilitas kantor yang memadai dapat mendorong tercapainya kinerja kerja yang baik sehingga pegawai dapat berupaya untuk melakukan pekerjaan dengan baik dan semaksimal mungkin.

Selain faktor fasilitas kerja, lingkungan kerja aparat desa juga tidak kalah pentingnya di dalam meningkatkan kinerja aparat desa. Dimana lingkungan kerja mampu menciptakan kondisi-kondisi material dan psikologis yang ada dalam pemerintahan desa. Maka dari itu pemerintahan desa harus menyediakan lingkungan kerja yang memadai seperti lingkungan fisik (tata ruang kantor yang nyaman, lingkungan yang bersih, pertukaran udara yang baik, warna, penerangan yang cukup maupun musik yang merdu), serta lingkungan non fisik (suasana kerja aparat, kesejahteraan aparat desa, hubungan antar sesama aparat desa, hubungan antar aparat desa dengan Kepala Desa, serta tempat ibadah.

\section{KESIMPULAN}

Berdasarkan hasil penelitian yang dilakukan, maka kesimpulan yang dapat dikemukakan dalam penelitian ini adalah sebagai berikut :

1. Ada pengaruh signifikan kepemimpinan terhadap kinerja perangkat desa di Kecamatan Kampar. Besarnya pengaruh kepemimpinan adalah 9,48\%.

2. Ada pengaruh signifikan lingkungan kerja terhadap kinerja perangkat desa di Kecamatan Kampar. Besarnya pengaruh lingkungan kerja adalah 9\%.

3. Ada pengaruh signifikan fasilitas kantor terhadap kinerja perangkat desa di Kecamatan Kampar. Besarnya pengaruh fasilitas kantor adalah 16,48\%.

4. Ada pengaruh signifikan kepemimpinan, lingkungan kerja, dan fasilitas kantor terhadap kinerja perangkat desa di Kecamatan Kampar. Besarnya pengaruh kepemimpinan, lingkungan kerja, dan fasilitas kantor terhadap kinerja perangkat desa di Kecamatan Kampar adalah 52,8\%

\section{DAFTAR PUSTAKA}

Ahmadi. Edy Anas, Herwidyaningtyas, Fristina Bhakti, Fatimah. Siti. 2020. The Influence Of Organizational Culture, Work Motivation, And Job Satisfaction On Management Lecturer Performance (Empirical Study At Higher Education In The Residency Of Bojonegoro. Journal Of Industrial Engineering \& Management Research. Jilid 1. Terbitan 3 Halaman 76-83

Ali, Muhammad. 2013. Penelitian Kependidikan Prosedur dan Strategi. Penerbit Angkasa, Bandung.

Ekaningsih, Sri Ana. 2012. Pengaruh Motivasi Kerja terhadap Kinerja dengan Persepsi Lingkungan Kerja sebagai Variabel Pemoderasi (Studi pada Satuan Polisi Pamong 
Praja Kota Surakarta). Jurnal Ilmu Sosial. Volume 4 No.1 Surakarta: Sekolah Tinggi Ilmu Ekonomi Bulungan Tarakan.

Hamalik, Oemar. 2007. Manajemen Pelatihan Ketenagakerjaan Pendekatan Terpadu. Penerbit PT. Bumi Aksara, Jakarta.

Mangkunegara, A.A Anwar Prabu. 2009. Manajemen Sumber Daya Manusia. Penerbit PT Remaja Rosdakarya, Jakarta.

Mathis, Robert L dan Jhon H. Jackson. 2002. Manajemen Sumber Daya Manusia. Penerbit Salemba Empat. Jakarta

Moenir, A.S. 1987. Pendekatan Manusiawi dan Organisasi Terhadap Pembinaan Kepegawaian. Penerbit Gunung Agung, Jakarata.

Murtiningsih, Endang. 2012. Pengaruh Motivasi, Kesejahteraan dan Fasilitas Kerja terhadap Kinerja Anggota Satuan Polisi Pamong Praja Kabupaten Kediri. Jurnal Ilmu Manajemen. Vol. 1. Hal 81 - 92

Nitisemito, S. Alex dan Burhan Umar. 2004. Wawasan Studi Kelayakan dan Evaluasi Proyek, Edisi Revisi. Penerbit PT. Bumi Aksara, Jakarata.

Priansa, Donni Juni dan Garindra Agus. 2013. Manajemen Perkantoran (Efektif Efisien dan Profesional). Penerbit Alfabeta. Jakarta.

Posuma, O. Christilia. 2013. Kompetensi, Kompensasi, dan Kepemimpinan Pengaruhnya terhadap Kinerja Karyawan pada Rumah Sakit Ratumbusyang Manado. Vol. 1 No. 4 Hal. 646-656

Rivai, Veithzal. 2006. Kepemimpinan dan Perilaku Organisasi. Penerbit PT. Raja Grafindo Persada, Jakarta.

Sinambela, Lijan Poltak. 2012. Kinerja Pegawai Teori Pengukuran dan Implikasi. Penerbit Graha Ilmu, Yogyakarta.

Sugiyono. 2011. Metode Penelitian Kuantitatif Kualitatif dan R\&D. Penerbit Penerbit Alfabeta, Bandung.

Suharsimi, Arikunto. 2006. Prosedur Penelitian Suatu Pendekatan Praktek. Penerbit Rineka Cipta, Jakarta.

Sunindhia, YW dan Widiyanti Ninik. 1993. Kepemimpinan dalam Masyarakat Modern. PT. Rineka Cipta, Jakarta.

Wirawan. 2009. Evaluasi Kinerja Sumber Daya Manusia Teori, Aplikasi, dan Penelitian. Salemba Empat, Jakarta.

Umar, Husein.2004. Metode Riset Komunikasi Organisasi.Penerbit PT Gramedia Pustaka Utama, Jakarta. 